\title{
Łukasz Pasternak
}

\section{Zasady jawności oraz uczciwej konkurencji w postępowaniu o udzielenie zamówienia publicznego}

\section{STRESZCZENIE}

Zasady „zamówień publicznych” charakteryzują się szczególną doniosłością dla systemu zamówień publicznych, albowiem wskazują kierunki wykładni przepisów ustawy Prawo zamówień publicznych, jak również za ich pomocą można niejednokrotnie prawidłowo odczytać ratio legis danych unormowań prawnych. Przedmiotem niniejszego opracowania jest przedstawienie dwóch podstawowych zasad prawa zamówień publicznych, tj. zasady uczciwejkonkurencji i równego traktowania wykonawców oraz zasady jawności. Autor wskazuje na instytucjonalne przejawy ww. zasad w toku postępowania o udzielenie zamówienia publicznego oraz wskazuje naruszenia powyższych zasad, które pojawiają się w praktyce stosowania prawa.

Słowa kluczowe: zamówienia publiczne, nieuczciwa konkurencja, zasady prawne 


\title{
Łukasz Pasternak
}

\section{The Principles of Transparency and Fair Competition in the Procedure of Awarding Public Procurement}

\begin{abstract}
The principles of „Public Procurement” are important for the proper functioning of the public procurement system. There is no doubt that principles of public procurement system have a special significance for the above mentioned system, since they indicate the direction of interpretation of provisions of the public procurement law as well as they allow a proper interpretation of the meaning of legal norms. The purpose of this elaboration is to present two basic principles of the public procurement law, i.e. the principle of fair competition and equal treatment of economic operators as well as the principle of transparency. The Author indicates the institutional expression of these principles in the procedure of awarding public procurement and indicates the violations of the principles which occur in the practice of law.
\end{abstract}

Keywords: public procurement, unfair competition, legal principles 


\section{WPROWADZENIE}

Zasady „zamówień publicznych" mają istotne znaczenie dla prawidłowego funkcjonowania systemu zamówień publicznych, albowiem wskazują one kierunki wykładni poszczególnych przepisów ustawy z dnia 29 stycznia 2004 r. - Prawo zamówień publicznych ${ }^{1}$.

Przedmiotowe opracowanie podejmuje problematykę zasady jawności oraz uczciwej konkurencji łącznie, albowiem zasady te, choć odrębne, są ze sobą ściśle powiązane, o czym świadczy to, że:

1. obie są fundamentalnymi zasadami prawa zamówień publicznych i przenikają się na wielu etapach postępowania o udzielenie zamówienia publicznego,

2. wiele instytucji prawa zamówień publicznych stanowi instytucjonalny wyraz obu zasad jednocześnie, a przykładem może być art. 40 p.z.p., który nakłada na zamawiającego obowiązek ogłoszenia o zamówieniu. Zamawiający, ogłaszając o zamówieniu, nie tylko zapewnia wykonawcom równy dostęp do informacji o postępowaniu, ale również pozwala zweryfikować, czy ogłoszenie o zamówieniu publicznym nie narusza zasady równego traktowania wykonawców, np. ograniczając w sposób nieuzasadniony krąg podmiotów zdatnych do wykonania zamówienia.

Dodatkowo należy wskazać, że szczególnie istotny z punktu widzenia zamówień publicznych jest etap przygotowania postępowania, podczas którego zamawiający ustala warunki udziału w postępowaniu oraz dokonuje opisu przedmiotu zamówienia. Zasada jawności jest swego rodzaju mechanizmem kontrolnym, który pozwala skontrolować, czy działania zamawiającego nie naruszają zasad uczciwej konkurencji i równego traktowania wykonawców. Kolejnym argumentem przemawiającym za łącznym omówieniem obu zasad jest to, iż zasada jawności ma także pozytywny wpływ na rozwój konkurencji w zamówieniach publicznych, co dostrzega również prawodawca unijny ${ }^{2}$.

1 Dz. U. z 2013 r., poz. 984, tekst jedn., ze zm. (dalej: p.z.p.).

2 Zob. dyrektywa nr 2004/18/WE Parlamentu Europejskiego i Rady z dnia 31 marca 2004 r. w sprawie koordynacji procedur zamówień publicznych na roboty budowlane, dostawy i usługi - Dz.Urz. UE z 2004 r., 
Celem niniejszego opracowania jest zbadanie, czy postawiona teza badawcza jakoby zasada jawności oraz zasada uczciwej konkurencji stanowiły swoiste „drogowskazy" w interpretacji przepisów ustawy prawa zamówień publicznych, warunkowały treść przepisów zawartych w ustawie oraz warunkowały konkretne prawa i obowiązki uczestników postępowania o udzielenie zamówienia publicznego jest prawidłowa. Autor sygnalizuje również, że zasady prawa zamówień publicznych, a w szczególności zasada jawności oraz uczciwej konkurencji, są zasadami, które są najczęściej naruszane $\mathrm{w}$ toku postępowania o udzielenie zamówienia publicznego.

\section{ZASADA UCZCIWEJ KONKURENCJI I RÓWNEGO TRAKTOWANIA WYKONAWCÓW}

Zapewnienie mechanizmów konkurencji w toku postępowania o udzielenie zamówienia publicznego jest na tyle istotne, że w art. 7 ust. 1 p.z.p. wprost wskazano, iż - „zamawiający przygotowuje i przeprowadza postępowanie o udzielenie zamówienia w sposób zapewniający zachowanie uczciwej konkurencji oraz równe traktowanie wykonawców".

Zasada uczciwej konkurencji i równego traktowania wykonawców stanowi fundament nie tylko w polskim, ale również w europejskim systemie zamówień publicznych. Na taką konstatację pozwala brzmienie artykułu 2 dyrektywy 2004/17/WE Parlamentu Europejskiego i Rady z dnia 31 marca 2004 r. w sprawie koordynacji procedur udzielania zamówień publicznych na roboty budowlane, dostawy i usługi ${ }^{3}$. Zgodnie z wyżej wskazanym prze-

I., 134/114 oraz dyrektywa Parlamentu Europejskiego i Rady z dnia 31 marca 2004 r. koordynująca procedury udzielania zamówień przez podmioty działające w sektorach gospodarki wodnej, energetyki, transportu i usług pocztowych - Dz.Urz. UE z 2004 r., I., 134/1.

$\mathrm{Na}$ istotę zasady przejrzystości niejednokrotnie zwracał również uwagę ETS w swoich orzeczeniach, np. orzeczeniu w sprawie Telaustria Verlags $\mathrm{GmbH}$, Telefonadress $\mathrm{GmbH}$ przeciwko Telekom Austria AG, Zbiór Orzeczeń 2000, s. I-10745, pkt 60-62; orzeczeniu w sprawie C-231/03 Consorzio Aziende Metano (Coname) przeciwko Commune di Cingiade'Botti, Zbiór Orzeczeń 2005, s. 1-7287, pkt 16-22. Szerzej o zasadzie jawności w zamówieniach publicznych w świetle dyrektyw UE zob. M. Szydło, Zasada przejrzystości w zamówieniach publicznych, do których nie stosuje się lub stosuje sięjedynie częściowo przepisy wspólnotowych dyrektyw o zamówieniach publicznych, "Samorząd Terytorialny" 2008, nr 7-8, s. 76-100.

3 Dz.Urz. UE L z dnia 30 kwietnia 2004 r. 
pisem instytucje zamawiające zapewniają równe oraz niedyskryminujące traktowanie wykonawców oraz działają w sposób przejrzysty. Zasada uczciwej konkurencji stanowi również przejaw zasady niedyskryminacji wyrażonej w Traktacie o Funkcjonowaniu Unii Europejskiej ${ }^{4}$. Przejawy zasady uczciwej konkurencji i równego traktowania wykonawców można dostrzec na każdym etapie postępowania o udzielenie zamówienia publicznego, tj. na etapie jego przygotowania, jak i na etapie jego prowadzenia.

Brzmienie art. 7 ust. 1 p.z.p. pozwala skonstatować, iż głównym adresatem tego przepisu jest zamawiający, albowiem to na nim ciąży obowiązek zapewnienia przestrzegania zasady uczciwej konkurencji i równego traktowania wykonawców. Zasada uczciwej konkurencji i równego traktowania wykonawców odgrywa szczególne znaczenie już na etapie przygotowania postępowania o udzielenie zamówienia publicznego, podczas którego zamawiający ustala warunki udziału w postępowaniu oraz opisuje przedmiot zamówienia ${ }^{5}$. Przejawy ww. zasady można dostrzec w art. 29 ust. 1-3 p.z.p., zgodnie z którym „przedmiot zamówienia opisuje się w sposób jednoznaczny i wyczerpujący, za pomocą dostatecznie dokładnych i zrozumiałych określeń, uwzględniając wszystkie wymagania i okoliczności mogące mieć wpływ na sporządzenie oferty“.

Przedmiotu zamówienia nie można opisywać w sposób, który mógłby utrudniać uczciwą konkurencję. Tym samym zakazane jest dokonywanie opisu przedmiotu zamówienia poprzez wskazanie na konkretny produkt, jak również sporządzenie takiego opisu, który hipotetycznie mógłby wpłynąć na konkurencję na rynku. Konieczna jest więc eliminacja z opisu przedmiotu zamówienia wszelkich sformułowań, które wskazywałyby na konkretnego producenta czy usługodawcę. Zamawiający, dokonując opisu zamówienia, powinien wskazywać na cechy przedmiotu zamówienia, które mają dla zamawiającego kluczowe znaczenie. Zamawiający, dokonując opisu przedmiotu zamówienia powinien również brać pod uwagę warunki rynku właściwego dla danych dostaw, usług czy robót budowlanych. Dokonywanie opisu przedmiotu zamówienia na podstawie katalogów jednego z producentów, podział na pakiety (części), tak że wszystkie produkty w danym pakiecie może dostarczyć tylko jeden wykonawca, lub celowe łączenie w opisie przedmiotu zamówienia kilku dóbr, których uzyskanie jest możliwe oddzielnie

4 Por. P. Trepte, Public Procurement in the EU. A practicioner's Guide, wyd. 2, 0xford, s. 5-7

5 Por. J. Pieróg, Prawo zamówień publicznych. Komentarz, wyd. 12, Warszawa 2013, s. 67. 
(na różnych rynkach), tak by całość zamówienia była poddana mniejszej konkurencji, jest działaniem utrudniającym uczciwą konkurencję.

Przedmiotu zamówienia nie można opisywać przez wskazanie znaków towarowych, patentów lub pochodzenia, chyba że jest to uzasadnione specyfiką przedmiotu zamówienia i zamawiający nie może opisać przedmiotu zamówienia za pomocą dostatecznie dokładnych określeń, a wskazaniu takiemu towarzyszą wyrazy „lub równoważny”.

Opis przedmiotu zamówienia oraz ustalenie warunków udziału w postępowaniu należą do najistotniejszych elementów postępowania, albowiem od nich zależy udział poszczególnych wykonawców w postępowaniu o udzielenie zamówienia publicznego. Powszechnie nie budzi wątpliwości to, iż formułowanie warunków udziału w postępowaniu o udzielenie zamówienia publicznego może stanowić "narzędzie” w ręku zamawiającego, za pomocą którego zamawiający ograniczy dostęp wykonawców do postępowania ${ }^{6}$. Wobec powyższego można zaryzykować twierdzenie, że zasada uczciwej konkurencji i równego traktowania wykonawców musi być stosowana już na samym początku przygotowania postępowania o udzielenie zamówienia publicznego.

W orzecznictwie Krajowej Izby Odwoławczej oraz orzecznictwie sądów powszechnych wskazuje się, że „zarówno przygotowanie, jak i przeprowadzenie postępowania o udzielenie zamówienia publicznego musi odbywać się z poszanowaniem zasady uczciwej konkurencji i równego traktowania wykonawców, a zamawiający obowiązany jest do eliminowania z opisu przedmiotu zamówienia wszelkich sformułowań, które mogłyby wskazywać na konkretnego wykonawcę, bądź które eliminowałyby konkretnych wykonawców, uniemożliwiając im złożenie oferty lub powodowałyby sytuację, w której poszczególni wykonawcy pozostawaliby w pozycji uprzywilejowanej w stosunku do innych wykonawców"7 ${ }^{\prime \prime}$ Ponadto zakazane jest stosowanie nadmiernych i nieuzasadnionych wymogów, które utrudniałyby dostęp do zamówienia. $Z$ naruszeniem zasady uczciwej konkurencji i równego traktowania wykonawców mamy do czynienia również wówczas, gdy wykonawcy co prawda mogli złożyć ważną i odpowiadającą

6 Zob. ibidem, s. 161.

7 Zob. wyrok Sądu Apelacyjnego w Warszawie z dnia 24 stycznia 2012 r., VI ACa 965/11, LEX nr 1315895; wyrok KIO z dnia 26 kwietnia 2011 r., KIO 752/11, LEX 795170.

Szerzej zob. P. Banasik, Najczęstsze błędy i uchybienia w postępowaniu o udzielenie zamówienia publicznego, Wrocław 2012, s. 113-116. 
Specyfikacji Istotnych Warunków Zamówienia ofertę, ale z uwagi na ukształtowanie kryteriów oceny oferty, oferta taka nie mogła realnie konkurować z ofertami innych wykonawców ${ }^{8}$.

Częstym przykładem naruszenia zasady uczciwej konkurencji i równego traktowania wykonawców mającym miejsce przy opisie przedmiotu zamówienia jest dokonanie opisu przedmiotu zamówienia przez zamawiającego na podstawie kryteriów, jakimi posługuje się dany producent, gdy istnieje możliwość opisu przedmiotu zamówienia za pomocą innych kryteriów aniżeli kryteria określonego producenta. Krajowa Izba Odwoławcza wskazuje również, iż niedopuszczalna, a tym samym naruszająca zasadę uczciwej konkurencji i równego traktowania wykonawców jest sytuacja, w której np. zamawiający grupuje leki w pakiety w taki sposób, który a priori eliminuje z postępowania o udzielenie zamówienia publicznego dostawców leków, którzy nie są związani umowami z producentami jednego z leków, zawartego w pakiecie. Pamiętać przy tym należy, że w interesie wykonawcy (tudzież odwołującego) jest wykazanie, iż w danym przypadku zamawiający pogrupował leki w sposób dyskryminujący czy eliminujący z postępowania innych wykonawców ${ }^{9}$.

Wyjątek od powyższej zasady przewiduje art. 29 ust. 3 p.z.p., którego brzmienie pozwala przyjąć, że z naruszeniem ww. zasady nie będziemy mieli do czynienia wówczas, gdy opis przedmiotu zamówienia wskazujący na konkretnego producenta wynika ze specyfiki przedmiotu zamówienia i zamawiający nie może opisać przedmiotu zamówienia za pomocą dostatecznie dokładnych określeń, a wskazaniu takiemu towarzyszą wyrazy „lub równoważny”.

Zasada uczciwej konkurencji i równego traktowania wykonawców w toku postępowania o udzielenie zamówienia publicznego przejawia się również m.in. poprzez zapewnienie wykonawcom równego dostępu do informacji o zamówieniu przez publikację ogłoszenia o zamówieniu, publikację Specyfikacji Istotnych Warunków Zamówienia ${ }^{10}$.

8 Zob. wyrok KIO z dnia 11 stycznia 2012 r., KI0 2816/11, Zamówienia Publiczne w Orzecznictwie, z. 12, Warszawa 2012, s. 10.

9 Zob. wyrok KIO z dnia 19 listopada 2012 r., KIO 2441/12, LEX 1237673; przykładowo szerzej na temat opisu przedmiotu zamówienia zob. M. Bubnowski, Opis przedmiotu zamówienia za pomoca znaku towarowego, komentarz praktyczny, $\mathrm{ABC} \mathrm{nr} 96021$.

10 Por. wyrok KIO z dnia 28 grudnia 2012 r., KIO 2741/12, LEX nr 1256955; por. wyrok KIO z dnia 24 stycznia 2012 r., KIO 54/12, LEX 1109109.

Uzupełniająco należy wskazać, iż przejawem zasady uczciwej konkurencji i równego traktowania wykonawców w postępowaniu o udzielenie zamówienia publicznego jest obowiązek dokonania przez 
Uzupełnieniem zasady uczciwej konkurencji jest zasada równego traktowania wykonawców. Zasada równego traktowania wykonawców w postępowaniu o udzielenie zamówienia publicznego wyznaczana jest przez ogólną zasadę zakazującą dyskryminacji, która została zawarta w art. 12 TWE. Przepis art. 12 może być stosowany bezpośrednio również w stosunku do postępowań w sprawie udzielania zamówienia publicznego. Dlatego zasada ta obejmuje swoim zasięgiem również zamówienia, do których nie ma obowiązku stosowania ustawy - Prawo zamówień publicznych ${ }^{11}$.

Równe traktowanie wykonawców nakazuje zamawiającemu ich równe traktowanie na każdym etapie postępowania, bez stosowania przywilejów czy środków dyskryminujących poszczególnych wykonawców ze względu na ich właściwości. Przestrzeganie zasady równego traktowania wykonawców polega na stosowaniu jednej miary do wszystkich wykonawców znajdujących się w tej samej lub podobnej sytuacji, nie zaś na jednakowej ocenie wykonawców ${ }^{12}$.

Praktyka stosowania prawa pokazuje, iż znaczenie tej zasady w szczególności objawia się na etapie prowadzenia przez zamawiającego postępowania, gdzie zamawiający jest zobowiązany do zapewnienia jednakowego dostępu wykonawcom do przekazywanych dokumentów i informacji. Realizacji tego celu sprzyjają: ogłoszenie o zamówieniu (ewentualnie zaproszenie do składania ofert), przepisy regulujące sporządzanie oraz publikację Specyfikacji Istotnych Warunków Zamówienia, jak również instytucja wyjaśnień treści SIWZ. Dodatkowym przejawem zasady równego traktowania wykonawców jest nakaz nałożony na zamawiającego w zakresie eliminacji z postępowania o udzielenie zamówienia publicznego wykonawców, którzy dopuszczają się względem siebie czynów nieuczciwej konkurencji. Zgodnie z art. 89 ust. 1 pkt 3 p.z.p. - ofertę wykonawcy dopuszczającego się czynu nieuczciwej konkurencji zamawiający winien odrzucić. Zamawiający ma również obowiązek zapewnić wszystkim wykonawcom

zamawiającego jednoznacznego opisu oceny spełnienia warunków udziału w postępowaniu - zob. wyrok KIO z dnia 21 lutego 2012 r., KIO 275/12, LEX nr 1127008; por. wyrok KIO z dnia 13 lutego 2012 r., KIO 185/12, KIO 221/12, LEX nr 1124981; por. wyrok KIO z dnia 24 stycznia 2012 r., KIO 54/12, LEX 1109109. Podobnie ocena przez zamawiającego ofert w sposób dowolny, a nie na podstawie sformułowań określonych w SIWZ, może skutkować naruszeniem zasady uczciwej konkurencji i równego traktowania wykonawców - zob. wyrok KIO z dnia 30 grudnia 2011 r., KIO 2702/11, LEX nr 1103387; por. wyrok KIO z dnia 6 grudnia 2010 r., KIO/UZP 2550/10, LEX nr 707516.

11 Zob. K. Strzyczkowski, Prawo gospodarcze publiczne, wyd. 5, Warszawa 2009, s. 594.

12 Zob. D. Koba, Zamówienia na dostawy i usługi. Poradnik, Warszawa 2004, s. 17. 
dostęp do istotnych dla postępowania informacji w jednakowym czasie. Przykładowo zamawiający, który nie udziela wyjaśnień wykonawcy, swoim zachowaniem narusza zasadę określoną $\mathrm{w}$ art. 7 ust. 1 p.z.p. ${ }^{13}$

Praktyka stosowania ustawy - Prawo zamówień publicznych pokazuje, że zamawiający niejednokrotnie naruszają zasadę uczciwej konkurencji i równego traktowania wykonawców poprzez różne traktowanie poszczególnych wykonawców w postępowaniu o udzielenie zamówienia ${ }^{14}$. Zachowania takie, niekiedy mające podłoże korupcyjne czy - nieco szerzej - kryminogenne, sprawiają, że zaburzone zostają fundamentalne zasady postępowania o udzielenie zamówienia publicznego. Zachowania zamawiających skutkujące nierównym traktowaniem wykonawców w postępowaniu o udzielenie zamówienia publicznego przejawiają się m.in. w opracowaniu przez zamawiającego Specyfikacji Istotnych Warunków Zamówienia w taki sposób, który umożliwi tylko niektórym wykonawcom dostęp do udziału w postępowaniu o udzielenie zamówienia publicznego lub stawiał ich będzie w uprzywilejowanej w stosunku do innych pozycji ${ }^{15}$. Naruszenie zasady uczciwej konkurencji i równego traktowania wykonawców wiąże się również ze stosowaniem niekonkurencyjnych trybów udzielania zamówień publicznych w sytuacji, gdy nie ziściły się przesłanki ich zastosowania. Skutki naruszenia zasady uczciwej konkurencji i równego traktowania wykonawców mogą być daleko idące, albowiem powyższa zasada może prowadzić do stwierdzenia nieważności umowy zawartej w wyniku postępowania o udzielenie zamówienia publicznego.

Zasada uczciwej konkurencji i równego traktowania wykonawców nakładająca na zamawiających, jak i wykonawców szereg obowiązków, nie ma charakteru zasady absolutnej, albowiem dopuszczalne są od niej wyjątki. Wyjątki te muszą być wyraźnie przewidziane przez ustawę - Prawo zamówień publicznych. Jednym z przykładów wyjątku od zasady uczciwej konkurencji i równego traktowania wykonawców jest zastosowanie trybu

\footnotetext{
13 Wyrok ZAUZP z dnia 16 sierpnia 2005 r., UZP/Z0/0-2144/05, LEX nr 1068028.

14 Tak też J. Pieróg, który wskazuje, że, ,ustawa nie pozwala faworyzować ani dyskryminować wykonawców z jakiegokolwiek powodu, poza rygorami przewidzianymi dla zapewnienia uczciwej konkurencji" - J. Pieróg, Prawo zamówień..., op. cit., s. 68. Tak też Z. Czarnik w: S. Babiarz, Z. Czarnik, P. Janda, P. Pełczyńśki, Prawo zamówień publicznych. Komentarz, wyd. 3, Warszawa 2013, s. 124-125 - autor ten wskazuje, iż analiza orzecznictwa pozwala przyjąć, że judykatura usiłuje elastycznie podchodzić do zasady uczciwej konkurencji poprzez dopuszczanie licznych modyfikacji w ramach postępowań, z uwzględnieniem tego, by nie naruszyć istoty samej konkurencji.

15 Por. wyrok Sądu Okręgowego w Lublinie z dnia 9 listopada 2005 r., II Ca 587/05, LEX 570334.
} 
zamówień z wolnej ręki uregulowanego w art. 67 i nast. p.z.p., wg którego zamawiający może dokonywać „,zakupu dóbr i usług” w trybie wykluczającym mechanizmy konkurencji.

Mimo iż ustawa - Prawo zamówień publicznych określa przypadki zastosowania trybu zamówień z wolnej ręki, w praktyce nierzadko dochodzi do sytuacji, w których podmioty obowiązane do stosowania p.z.p. nadużywają tego trybu, udzielając zamówienia publicznego w sposób sprzeczny z postanowieniami tej ustawy. Przykładem nadużycia zastosowania trybu przetargowego może być udzielenie zamówienia z wolnej ręki w sytuacji, gdy w danym miejscu i czasie jest zasadne domniemanie, że istnieje jeden lub więcej wykonawców mogących świadczyć usługi objęte przedmiotem zamówienia ${ }^{16}$.

\section{ZAKAZ ZMIANY WYKONAWCY JAKO WYNIK WYSTĘPOWANIA ZASADY UCZCIWEJ KONKURENCJI}

Zasada udzielenia zamówienia publicznego wykonawcy wybranemu zgodnie z przepisami ustawy - Prawo zamówień publicznych została powiązana z zasadą uczciwej konkurencji i równego traktowania wykonawców, co potwierdza umiejscowienie tej zasady w art. 7 ust. 3 p.z.p. ${ }^{17}$ Brzmienie art. 7 ust. 3 p.z.p. prowadzi do jednoznacznej konstatacji, iż ustawodawca co do zasady zakazuje dokonywania cesji praw wynikających z umowy lub przejęcia długów na rzecz wykonawców lub przez podmioty nieuczestniczące $\mathrm{w}$ postępowaniu o udzielenie zamówienia publicznego ${ }^{18}$. Tezę tę potwierdza również Sąd Najwyższy, który wskazuje, że „niedopuszczalna jest zmiana podmiotowa umowy zawartej w następstwie przetargu, umożliwiająca przejęcie zamówienia publicznego"19. Sąd Najwyższy stoi na sta-

16 Por. wyrok Sądu Apelacyjnego w Warszawie z dnia 21 stycznia 2015 r., I ACa 1201/14.

17 Zgodnie z art. 7 ust. 3 p.z.p. „zamówienia udziela się wyłącznie wykonawcy wybranemu zgodnie z przepisami ustawy".

18 Zob. wyrok KIO z dnia 17 grudnia 2012 r., KI0 26227/12, LEX nr 1254811.

19 Zob. wyrok SN z dnia 13 stycznia 2004 r., V CK 97/03, OSNC 2005, nr 2, poz. 34.

Niedopuszczalne są również zmiany podmiotowe polegające na wstąpieniu podmiotu trzeciego w charakterze wykonawcy do konsorcjum, które wygrało przetarg i zawarło umowę z zamawiającym. Takie zmiany są sprzeczne nie tylko $z$ art. 7 ust. 3 p.z.p., ale również z art. 144 p.z.p., który zakazuje 
nowisku, że zmiana podmiotowa umowy zawartej w następstwie przetargu w drodze tzw. sukcesji syngularnej skutkowałaby obejściem obowiązujących przepisów prawa i w rezultacie pociągałaby za sobą nieważność zawartej umowy ${ }^{20}$. Powyższe potwierdza orzecznictwo sądów unijnych wskazujące, że zmiany w postanowieniach zamówienia publicznego $\mathrm{w}$ czasie jego trwania stanowią udzielenie nowego zamówienia, jeżeli charakteryzują się one cechami w sposób istotny odbiegającymi od postanowień pierwotnego zamówienia. Tak więc zmiana wykonawcy, któremu instytucja zamawiająca udzieliła zamówienia publicznego, stanowi istotną zmianę danego zamówienia ${ }^{21}$.

Przedstawiciele doktryny opowiadający się za zakazem udzielenia zamówienia publicznego podmiotowi innemu aniżeli podmiot wybrany zgodnie z przepisami p.z.p. trafnie zauważaja, iż wyżej wskazana zasada nie ma charakteru zasady absolutnej, albowiem dopuszcza pewne wyjątki od jej stosowania. Do takich wyjątków zalicza się: sukcesję uniwersalną wynikającą m.in. z połączenia spółek; przeniesienia całego majątku spółki przejmowanej na spółkę przejmującą; podziału spółki; następstwa prawnego w przypadku przekształcenia np. spółki cywilnej w spółkę jawną; nabycia przedsiębiorstwa w rozumieniu art. $55^{4}$ k.c.; cesji wierzytelności, jak również kumulatywnego przystąpienia do długu. Takie zmiany podmiotowe podyktowane ww. okolicznościami są zgodne z przepisami prawa zamówień publicznych, albowiem są one uzasadnione zmianami organizacyjnymi występującymi po stronie wykonawcy postępowania o udzielenie zamówienia publicznego ${ }^{22}$.

Jednocześnie zauważyć należy, iż art. 7 ust. 3 p.z.p., nakazujący udzielić zamówienia wykonawcy wybranemu zgodnie z przepisami ustawy, nie odnosi się do zagadnienia związanego z możliwością zmian podmiotowych

istotnych zmian umowy w stosunku do treści oferty, na podstawie której dokonano wyboru wykonawcy. Wstąpienie podmiotu trzeciego może polegać tylko na kumulatywnym przystąpieniu do długu lub może być wynikiem sukcesji uniwersalnej. Natomiast niedopuszczalna jest sytuacja, w której podmiot trzeci wstąpi do konsorcjum, które zawarło umowę z zamawiającym, a następnie dokonana zostanie zmiana umowy z zamawiającym. Na takim stanowisku stoi zarówno doktryna, jak i orzecznictwo oraz obowiązujące przepisy ustawy - Prawo zamówień publicznych. Uzasadnione jest to faktem, iż takie wstąpienie podmiotu 3 w prawa i obowiązki podmiotów, które wygrały postępowanie mogłoby, a nawet prowadziłoby do obejścia przepisów ustawy, a w szczególności art. 7 ust. 3 p.z.p.

20 Por. wyrok SN z dnia 27 czerwca 2003 r., IV CKN 302/01, 0SNC 2004, nr 9, poz. 147.

21 Orzeczenie z dnia 19 czerwca 2008 r. w sprawie C-454/06 pressetext Nachrichtenagenur GmbH przeciwko Republice Austrii.

22 Szerzej zob. R. Szostak w glosie do wyroku SN z dnia13 stycznia 2004 r., V CK 97/03, 0SP 2005, z. 2, s. 22. 
po stronie zamawiającego w postępowaniu o udzielenie zamówienia publicznego. Zmiana podmiotowa po stronie zamawiającego jest więc dopuszczalna na każdym etapie postępowania, aczkolwiek po zawarciu umowy o udzielenie zamówienia publicznego zmiana taka wymaga zgody wykonawcy ${ }^{23}$.

\section{ZASADA BEZSTRONNOŚCI I OBIEKTYWIZMU}

W doktrynie panują rozbieżności, czy zasada bezstronności i obiektywizmu stanowi samodzielną zasadę Prawa zamówień publicznych. Jedni autorzy opowiadają się za jej samodzielnościa, inni natomiast zajmują stanowisko przeciwne $^{24}$. Nie wdając się jednak w głębsze rozważania co do zasadności przypisania tej zasadzie samodzielnego charakteru, wskazać należy, że powyższa zasada została ujęta $w$ art. 7 ust. 2 p.z.p. Stosownie do postanowień ww. przepisu „,czynności związane z przygotowaniem oraz przeprowadzeniem postępowania o udzielenie zamówienia wykonują osoby zapewniające bezstronność i obiektywizm".

Zasada bezstronności i obiektywizmu nakłada na zamawiającego obowiązek działania w sposób bezstronny i niezależny, niestwarzający sytuacji, w której jeden z wykonawców pozostawałby w pozycji uprzywilejowanej w stosunku do innych. Zamawiający musi zatem powstrzymać się od wszelkich arbitralnych działań, które mogłyby mieć negatywny wpływ na sytuację wykonawców. Zakazuje się również wszelkich form faworyzowania wykonawców, bez względu na motywy takiego działania. Zasada bezstronności i obiektywizmu prowadzi również do wniosku, iż na wynik postę-

23 Por. uchwała KIO z dnia 9 grudnia 2011 r., KIO/KD 88/11; uchwała KIO z dnia 4 stycznia 2012 r., KIO/KD 89/11.

${ }^{24}$ Za istnieniem zasady bezstronności i obiektywizmu jako samodzielnej zasady opowiada się m.in. Z. Czarnik w: S. Babiarz, Z. Czarnik, P. Janda, P. Pełczyński, Prawo zamówień publicznych. Komentarz, Warszawa 2010, s. 16. Odmienne stanowisko w tej kwestii zajmuje J. Pieróg, Prawo zamówień..., op. cit., s. 69, wskazując, że trudno znaleźć głębsze uzasadnienie dla stanowiska, iż zasada bezstronności i obiektywizmu stanowi samodzielną zasadę zamówień publicznych poza aspektem formalnego wyodrębnienia tej regulacji w art. 7 ust. 2 p.z.p. W ocenie tego autora zasada ta jest uzupełnieniem zasady uczciwej konkurencji; podobnie Z. Czarnik, chociaż określa art. 7 ust. 2 jako samodzielną zasadę. Z kolei M. Stachowiak zasadę bezstronności i obiektywizmu traktuje jako gwarancję zachowania uczciwej konkurencji w postępowaniu o udzielenie zamówienia publicznego - M. Stachowiak w: M. Stachowiak, J. Kerzykowski, W. Dzierżanowski, Prawo zamówień publicznych. Komentarz, LEX 2012. 
powania nie powinna mieć wpływu jakakolwiek sytuacja rodzinna lub narodowa, jak również interes osobisty czy polityczna presja ${ }^{25}$. Nie ulega wątpliwości, iż bez zasady bezstronności i obiektywizmu niemożliwe byłoby zapewnienie skuteczności pozostałym zasadom Prawa zamówień publicznych, gdyż trudno byłoby mówić o realnej konkurencji oraz równości wykonawców bez obiektywizmu w wyborze wykonawcy czy jego braku przy ocenie ofert. Przejawem zasady bezstronności i obiektywizmu w postępowaniu o udzielenie zamówienia publicznego jest m.in. art. 17 p.z.p. zawierający nakaz wyłączenia z postępowania osób biorących udział w postępowaniu o udzielenie zamówienia publicznego, co do których istnieje wątpliwość co do ich bezstronności.

\section{ZASADA JAWNOŚCI POSTĘPOWANIA O UDZIELENIE ZAMÓWIENIA PUBLICZNEGO}

Zasada jawności postępowania o udzielnie zamówienia publicznego jest obecna na każdym etapie postępowania, tj. od momentu wszczęcia postępowania, w trakcie postępowania, aż do momentu wyboru oferty najkorzystniejszej lub wynegocjowania najkorzystniejszej umowy (w przypadku zamówień z wolnej ręki). Zasada jawności postępowania o udzielenie zamówienia publicznego stanowi gwarancję transparentności postępowania o udzielenie zamówienia publicznego. Prawodawca unijny, dostrzegając pozytywny wpływ tej zasady na postępowanie o udzielenie zamówienia publicznego, jak również rozwój konkurencji w zamówieniach publicznych, postanowił ująć ją w jednej z dyrektyw unijnych ${ }^{26}$.

25 Por. P. Banasik, Zasada bezstronności i obiektywizmu w postępowaniu o udzielenie zamówienia publicznego, komentarz praktyczny, ABC nr 107738; por. G. Mazurek, Nowelizacja ustawy - Prawo zamówień publicznych i jej wpływ na podmioty funkcjonujacce w ochronie zdrowia, komentarz praktyczny, $\mathrm{ABC}$ nr 163465.

26 Zob. dyrektywa nr 2004/18/WE Parlamentu Europejskiego i Rady z dnia 31 marca 2004 r. w sprawie koordynacji procedur zamówień publicznych na roboty budowlane, dostawy i usługi - Dz.Urz. UE z 2004 r., I., 134/114 oraz dyrektywa Parlamentu Europejskiego i Rady z dnia 31 marca 2004 r. koordynująca procedury udzielania zamówień przez podmioty działające w sektorach gospodarki wodnej, energetyki, transportu i usług pocztowych - Dz.Urz. UE z 2004 r., l., 134/1.

$\mathrm{Na}$ istotę zasady przejrzystości niejednokrotnie zwracał również uwagę ETS w swoich orzeczeniach, szczególnie: orzeczenie w sprawie Telaustria Verlags $\mathrm{GmbH}$, Telefonadress GmbH przeciwko Telekom Austria 
W doktrynie wskazuje się, że można wyróżnić dwa aspekty zasady jawności, tj. aspekt wewnętrzny - wobec uczestników postępowania, jak i aspekt zewnętrzny - względem wszystkich osób zainteresowanych przeprowadzaną procedura postępowania o udzielnie zamówienia publicznego ${ }^{27}$. Wskazać przy tym należy, że nie da się ściśle rozgraniczyć jawności zewnętrznej i jawności wewnętrznej postępowania o udzielenie zamówienia publicznego. W nauce prawa wskazuje się, iż zasada jawności nie tylko gwarantuje transparentność postępowania, ale ma również ogromne znaczenie w zwalczaniu patologii zawiązanych z zamówieniami publicznymi ${ }^{28}$, albowiem przyczynia się ona do ograniczania działań korupcyjnych w sferze zamówień publicznych.

Zasada jawności wyraża się m.in. w obowiązku publicznego otwarcia ofert, publikacji ogłoszeń o zamówieniu, jawności postępowania odwoławczego oraz jawności dokumentacji zebranej w sprawie. Publikacja ogłoszenia o zamówieniu nie tylko sprzyja przeciwdziałaniu czynnikom korupcjogennym, ale także stanowi gwarancję jawności oraz konkurencyjności w systemie zamówień publicznych. $Z$ zasadą jawności wiąże się szczegółowy przepis w zakresie regulacji miejsca publikacji ogłoszenia oraz jego elementów. Przykładowo należy zauważyć, że w postępowaniu, którego wartość przekracza równowartość 30000 euro, a jest mniejsza od kwot 134000 / 207000 euro dla dostaw lub usług w zależności od podmiotu będącego zamawiającym oraz 5186000 euro dla robót budowlanych, a w przypadku zamówień sektorowych kwot 414000 euro dla dostaw lub usług oraz 5186000 euro dla robót budowlanych, zamawiający wszczyna postępowanie przez publikację ogłoszenia o zamówieniu w Biuletynie Zamówień Publicznych na stronach portalu internetowego Urzędu Zamówień Publicznych. Powyższe kwoty określa rozporządzenie Prezesa Rady Ministrów z dnia 23 grudnia 2013 r. w sprawie kwot wartości zamówień oraz konkursów, od których jest uzależniony obowiązek przekazywania ogłoszeń Urzędowi Publikacji Unii Europejskiej (Dz.U. z 2013 r., poz. 1735). Rozporządzenie to wydane zostało na podstawie art. 11 ust. 8 p.z.p. Po zamieszczeniu ogłoszenia w Biuletynie zamawiający zamieszcza je w miejscu publicznie dostępnym w swojej siedzibie oraz na stronie internetowej, Jeżeli jednak

AG, Zbiór orzeczeń 2000, s. I-10745, pkt 60-62; orzeczenie w sprawie C-231/03 Consorzio Aziende Metano (Coname) przeciwko Commune di Cingiade' Botti, Zbiór orzeczeń 2005, s. I-7287, pkt 16-22.

27 Tak: P. Szustakiewicz, Zasady Prawa Zamówień Publicznych, Warszawa 2007, s. 172.

28 Por. P. Szustakiewicz, Zasady Zamówień Publicznych ,,'Radca Prawny” 2004, nr 3, s. 109. 
wartość zamówienia jest równa lub przewyższa ww. kwoty, zamawiający przekazuje ogłoszenie o zamówieniu Urzędowi Oficjalnych Publikacji Wspólnot Europejskich.

Zasada jawności postępowania przejawia się więc w kreowaniu jasnych i przejrzystych zasad ubiegania się o udzielenie zamówienia publicznego ${ }^{29}$. Podstawowym źródłem informacji o zamówieniu publicznym jest Biuletyn Zamówień Publicznych, za pomocą którego każdy zainteresowany ma dostęp do informacji o zamówieniach. Inną cechą zasady jawności, na którą wskazuje M. Stachowiak, jest realizacja praw obywatela do uzyskiwania informacji o działalności organów władzy publicznej, osób, które pełnią funkcje publiczne, a także jednostek samorządu terytorialnego, jak i zawodowego oraz innych podmiotów obowiązanych do stosowania ustawy p.z.p. ${ }^{30}$ A. Sołtysińska wskazuje, iż „szybki, tani i skuteczny dostęp do informacji o potencjalnym zamówieniu jest jedną z podstawowych gwarancji jawności i przejrzystości zamówień publicznych wspomagających efektywną realizację zasady równego traktowania wszystkich uczestników postępowania. Jego waga wynika z potrzeby zapewnienia równych szans wszystkim przedsiębiorcom już na samym początku postępowania"31.

Wskazać należy, iż zasada jawności postępowania o udzielenie zamówienia publicznego jest niezwykle istotna z punktu widzenia wolnego rynku, albowiem równy dostęp do informacji jest jednym z czynników o ogromnym znaczeniu dla gospodarki wolnorynkowej. Zasada jawności daje podstawy do stwierdzenia, czy w danej sytuacji doszło do naruszenia zasady równego traktowania wykonawców i uczciwej konkurencji ${ }^{32}$. Istotnym przejawem zasady jawności jest obowiązek sporządzenia protokołu postępowania o udzieleniu zamówienia publicznego. Szczegółowe regulacje prawne dotyczące sporządzenia protokołu z postępowania o udzielenie zamówienia publicznego zostały zawarte w rozporządzeniu Prezesa Rady Ministrów z dnia 26 października 2010 r. w sprawie protokołu postępowania o udzieleniu zamówienia publicznego ${ }^{33}$.

\footnotetext{
${ }^{29}$ Zob. D. Koba, op. cit., s. 19.

30 Por. M. Stachowiak, Komentarz do art. 8 ustawy - Prawo zamówień publicznych, [w:] W. Dzierżanowski, W. Jerzykowski, M. Stachowiak, Prawo zamówień publicznych. Komentarz, LEX 2012.

31 A. Sołtysińska, Zamówienia publiczne w Unii Europejskiej, Warszawa 2004, s. 165.

32 Zob. D. Koba, op. cit., s. 19.

33 Szerzej na temat protokołu w postępowaniu o udzielenie zamówienia publicznego zob. W. Bajda, Protokół postępowania o udzielenie zamówienia publicznego, Warszawa 2012.
} 
Z zasady jawności wynikają również takie uprawnienia wykonawców, jak możliwość żądania kopii dokumentów zgromadzonych w aktach postępowania czy możliwość wglądu do tych akt ${ }^{34}$. W doktrynie wskazuje się, że cechą charakterystyczną zasady jawności jest to, iż korzystający z uprawnień wynikających z ustawy nie ma obowiązku wykazania się interesem prawnym czy faktycznym w uzyskiwaniu informacji dotyczących toczącego się postępowania ${ }^{35}$.

Od zasady jawności postępowania o udzielenie zamówienia publicznego zostały przewidziane pewne wyjątki ${ }^{36}$, albowiem zamawiający wyłącznie w przypadkach określonych w ustawie może ograniczyć dostęp do informacji związanych z postępowaniem o udzielenie zamówienia. Ponadto nie podlegają ujawnieniu informacje stanowiące tajemnicę przedsiębiorstwa w rozumieniu ustawy o zwalczaniu nieuczciwej konkurencji ${ }^{37}$, jeżeli wykonawca, nie później niż w dniu składania ofert bądź wniosków o dopuszczenie do udziału w postępowaniu, dokonał zastrzeżenia, że informacje przez niego ujawnione nie mogą być udostępniane ${ }^{38}$. Ustawa jednocześnie wskazuje, jakie informacje nie mogą zostać zastrzeżone przez wykonawcę jako informacje stanowiące tajemnicę przedsiębiorstwa.

\section{PODSUMOWANIE}

Analiza występowania oraz stosowania zasady uczciwej konkurencji i równego traktowania wykonawców, jak również zasada jawności potwierdza, że zasady prawa zamówień publicznych powinny być traktowane jako ele-

\footnotetext{
34 Por. D. Winiarski, Audyt Zamówień Publicznych, Warszawa 2005, s. 23.

35 Zob. A. Grochocińska-Jarząbek, Zasada jawności a tajemnica przedsiębiorstwa w postępowaniu o udzielenie zamówienia publicznego ,,"Rejent" 2007, nr 12, s. 123-124.

36 Por. wyrok KIO z dnia 4 marca 2013 r., KIO 347/12, LEX nr 1295031.

37 Zgodnie z ustawą o zwalczaniu nieuczciwej konkurencji przez tajemnicę przedsiębiorstwa rozumie się niepodane do wiadomości publicznej informacje techniczne, technologiczne, organizacyjne przedsiębiorstwa lub inne informacje posiadające wartość gospodarczą, co do których przedsiębiorca podjął niezbędne działania w celu zachowania ich poufności.

38 Szerzej w sprawie tajemnicy przedsiębiorstwa w zamówieniach publicznych i ograniczenia zasady jawności przykładowo zob. P. Wójcik, Tajemnica przedsiębiorstwa w zamówieniach publicznych, Wrocław 2010.
} 
menty konstrukcyjne postępowania o udzielenie zamówienia publicznego lub jako swoiste „znaki drogowe”, za pomocą których można dokonać wykładni danego przepisu p.z.p. wtedy, gdy zachodzą problemy z jego interpretacją $^{39}$. Zasady zamówień publicznych podporządkowane są w znacznej mierze celom oraz wartościom aksjologicznym, jakie legły u podstaw sytemu zamówień publicznych. Zasady prawa zamówień publicznych mają zapewnić efektywne wydatkowanie środków publicznych oraz dostęp do zamówień publicznych podmiotom zainteresowanym i zdolnym do wykonania zamówienia publicznego. Zasady te mają także zapewnić transparentność postępowania o udzielenie zamówienia ${ }^{40}$. Adresaci norm prawa zamówień publicznych, którymi są zamawiający, jak i wykonawcy, obowiązani są przestrzegać zasad zamówień publicznych na każdym etapie postępowania o udzielenie zamówienia publicznego. Zasady prawa zamówień publicznych warunkują również liczne obowiązki uczestników postępowania, przykładowo obowiązki: ogłoszenia o zamówieniu, sporządzenia protokołu z postępowania, zapewnienia jawności dokumentacji przetargowej, dokonania przez zamawiającego publicznego otwarcia ofert czy przygotowania postępowania o udzielenie zamówienia publicznego w sposób, który nie będzie naruszał zasady uczciwej konkurencji i równego traktowania wykonawców. Analiza przepisów ustawy - Prawo zamówień publicznych pozwala przyjać, że w zasadniczej mierze obowiązki przestrzegania zasad prawa zamówień publicznych ciążą na zamawiającym, który jest „panem” postępowania o udzielenie zamówienia publicznego. Już w tym miejscu należy przyjąć, że zasada jawności pozwalająca na weryfikację działań zamawiającego jest niezbędna dla prawidłowego funkcjonowania systemu zamówień publicznych.

Praktyka stosowania prawa prowadzi do wniosku, iż zarówno wykonawcy, jak i sami zamawiający dopuszczają się licznych naruszeń zasad prawa zamówień publicznych, co w połączeniu z naruszeniem poszczególnych przepisów p.z.p. może mieć daleko idące konsekwencje dla całego postępowania o udzielenie zamówienia publicznego m.in. z tych względów, że skutkiem naruszenia zasady uczciwej konkurencji i równego traktowania

39 Tak też D. Szczepański, Zasada uczciwej konkurencji i równego traktowania wykonawców. Komentarz praktyczny, ABC nr 90981.

40 Por. wyrok KIO z dnia 19 marca 2013 r., 521/13, LEX nr 1303248. Zasady prawa zamówień publicznych mają również zapobiegać występowaniu zachowań o charakterze patologicznym, kryminogennym w tym obszarze życia gospodarczego. 
wykonawców może być stwierdzenie nieważności umowy zawartej w wyniku postępowania o udzielenie zamówienia publicznego.

Powyższe pozwala skonstatować, iż prawidłowe stosowanie zasad postępowania o udzielenie zamówienia publicznego oraz ich znajomość w znaczny sposób ułatwia zrozumienie rozległej materii zamówień publicznych, przez co poruszanie się w niej staje się dużo łatwiejsze. Ponadto prawidłowe stosowanie przepisów ustawy oraz uznawanie zasad prawa zamówień publicznych w sposób znaczący przyczynia się do zmniejszenia liczby odwołań kierowanych przez wykonawców w postępowaniu o udzielenie zamówienia publicznego oraz do prawidłowej realizacji celów ustawy - Prawo zamówień publicznych.

\section{BIBLIOGR AFIA}

Babiarz S., Czarnik Z., Janda P., Pełczyński P., Prawo zamózień publicznych. Komentarz, Warszawa 2010.

Babiarz S., Czarnik Z., Janda P., Pełczyński P., Prawo zamówień publicznych. Komentarz, wyd. 3, Warszawa 2013.

Bajda W., Protokót postępowania o udzielenie zamówienia publicznego, Warszawa 2012.

Banasik P., Najczęstsze błędy i uchybienia w postępowaniu o udzielenie zamówienia publicznego, Wrocław 2012.

Banasik P., Zasada bezstronności i obiektywizmu w postępowaniu o udzielenie zamówienia publicznego, komentarz praktyczny, ABC nr 107738.

Bubnowski M., Opis przedmiotu zamówienia za pomoca znaku towarowego, komentarz praktyczny, ABC nr 96021.

Grochocińska-Jarząbek A., Zasada jawności a tajemnica przedsiębiorstwa w postępowaniu o udzielenie zamówienia publicznego, „Rejent” 2007, nr 12.

Koba D., Zamówienia na dostawy i ustugi. Poradnik, Warszawa 2004.

Mazurek G., Nowelizacja ustawy - Prawo zamówień publicznych $i$ jej wplyw na podmioty funkcjonujace w ochronie zdrowia, komentarz praktyczny, ABC nr 163465.

Pieróg J., Prawo zamówień publicznych. Komentarz, wyd. 12, Warszawa 2013.

Sołtysińska A., Zamówienia publiczne w Unii Europejskiej, Warszawa 2004.

Stachowiak M., Komentarz do art. 8 ustawy - Prawo zamówień publicznych, [w:] M. Stachowiak, J. Jerzykowski, W. Dzierżanowski, Prawo zamówień publicznych. Komentarz, LEX 2012. 
Stachowiak M., Jerzykowski J., Dzierżanowski W., Prawo zamówień publicznych. Komentarz, LEX 2012.

Strzyczkowski K., Prawo gospodarcze publiczne, wyd. 5, Warszawa 2009.

Szczepański D., Zasada uczciwej konkurencji i równego traktowania wykonawców. Komentarz praktyczny, ABC nr 90981.

Szustakiewicz P., Zasady Prawa Zamówień Publicznych, Warszawa 2007.

Szustakiewicz P., Zasady zamówień publicznych, „Radca Prawny” 2004, nr 3.

Szydło M., Zasada przejrzystości w zamówieniach publicznych, do których nie stosuje się lub stosuje się jedynie częściowo przepisy wspólnotowych dyrektyw o zamówieniach publicznych, „Samorząd Terytorialny” 2008, nr 7-8.

Trepte P., Public Procurement in the EU. A practicioner's Guide, wyd. 2, Oxford.

Winiarski D., Audyt zamówień publicznych, Warszawa 2005.

Wójcik P., Tajemnica przedsiębiorstwa w zamówieniach publicznych, Wrocław 2010. 